KOŚCIÓŁ I PRAWO 10(23) 2021, nr 1, s. 161-173

DOI: http://dx.doi.org/10.18290/kip21101-9

\author{
Monika Niedźwiecka
}

\title{
THE CRIME OF OFFENDING RELIGIOUS FEELINGS - LEGAL ANALYSIS
}

\section{INTRODUCTION}

The data published by the Public Opinion and Research Center in the form of a communication on the study "Religiousness of Poles in the Last 20 Years" shows that in 2020 91\% of residents of Poland declared belonging to a religious denomination. The survey shows that $85 \%$ of people who declared religious affiliation expressed it in the form of attendance of services, religious meetings, group religious practises and prayer. More than $66 \%$ of persons stated in the survey that they acquired their faith at home and maintain the traditions in their adult life. ${ }^{1}$

The above-mentioned survey confirms that faith is one of the most important pillars of our life, that gives us strength and brings consolation in moments of doubt. Believers turn to God through prayer asking for his grace and support both in day-to-day life and in times of crisis when it is difficult to find the sense of what is happening to us. The importance of faith in people's lives is also confirmed in the legal system, which serves to protect our rights and freedoms. One on them is the freedom of conscience and belief, which must be perceived as a personal fundamental right [Cebula 2011, 28-30] as it is a principal value included in the Constitution

MoniKa NiedźwIECKA, M.A. - Ph.D. student, Faculty of Law and Administration, the University of Szczecin; correspondence address: ul. Narutowicza 17A, 70-240 Szczecin, Poland; e-mail: monika.niedzwiecka@usz.edu.pl; https://orcid.org/0000-00024341-5324

${ }^{1}$ See https://cbos.pl/SPISKOM.POL/2020/K_063_20.PDF [accessed: 21.05.2021]. 
and deeply rooted in the regime of contemporary democratic states. It is directly guaranteed in Art. 53 sect. 1 of the Constitution of the Republic of Poland of 2 April 1997, according to which "Freedom of conscience and religion shall be ensured to everyone." ${ }^{2}$ Therefore, a very specific right results from Art. 53 of the Constitution, which is given to everyone because it is independent of citizenship, place of stay or residence. As pointed out by L. Garlicki, this right may be brought down to a demand for limiting state interference which may inhibit or entirely disallow free human activity of their own choosing in the religious dimension [Garlicki 2009, 101]. The literature commonly agrees that the freedom of conscience is associated with the right to have one's own worldview which may be perceived as a certain set of beliefs, norms or opinions and also attitudes that determine a person's behaviour towards himself and the environment [Pyclik 2002, 437-38; Garlicki 2009, 105].

Even though the Constitution includes an expression "freedom of conscience and religion" while other laws, including the Criminal Code, ${ }^{3}$ use the term "freedom of conscience and belief," legal scholars and commentators have no doubt that it concerns the same freedom. The scope and manner of interpretation of the freedom analysed have their source in the national legal order and result mainly from the basic law. However, there are also other factors that may affect its form and understanding. A very big role in this aspect is played by legal scholarly writings and legal commentary as well as international law regulations and judicial activity of courts which subject the content and interpretation of this freedom to a constant process of change.

Chapter XXIV of the Criminal Code "Offences against Freedom of Conscience and Religion" has three articles (194-196) which implement the constitutional principle of freedom of conscience and religion. This study analyses Art. $196 \mathrm{CC}$, according to which "anyone who offends the religious feelings of others by publically blaspheming an object of religious worship or a place dedicated to the public celebration of religious rites is liable to a fine, the restriction of liberty or imprisonment for up to two

\footnotetext{
${ }^{2}$ Constitution of the Republic of Poland of 2 April 1997, Journal of Laws No. 78, item 483 as amended.

${ }^{3}$ Act of 6 June 1997, the Criminal Code, Journal of Laws of 2020, item 1444 as amended [henceforth cited as: $\mathrm{CC}$ ].
} 
years." This regulation is extremely important due to the subject-matter of protection and numerous interpretation doubts that its content triggers. Data published by the General Police Headquarters demonstrates that in 2019, 80 proceedings under Art. 16 CC were initiated, of which only 58 were referred to court. ${ }^{4}$

The aim of this study is to conduct a legal analysis of the content of Art. $196 \mathrm{CC}$, including identification of the subject-matter of protection as well as the material and personal scope of the crime stipulated in its content. Moreover, the author points to interpretative problems that the term "religious feelings" triggers against the regulation in question.

\section{SUBJECT-MATTER OF PROTECTION}

The Criminal Code in force stipulates in its Art. 196 CC that anyone who offends the religious feelings of others by publically blaspheming an object of religious worship of a place dedicated to the public celebration of religious rites commits a summary offence for which they are liable to a fine, the restriction of liberty or imprisonment for up to two years. Given the content of Art. $196 \mathrm{CC}$, it needs to be pointed out that the subjectmatter of protection in this case involves religious feelings of believers, which constitute an emotional attitude of a certain group to the belief they adhere to also expressed in the right to the protection of respect for the values professed by them and places and objects of worship [Hypś 2015, 976]. Therefore, the state protects a person's freedom of their faith, which is at the same time an expression of tolerance to citizens' worldviews and of state neutrality in matters of faith [Wojciechowska 2001, 84-86].

Even though the freedom of conscience and belief constitutes our fundamental right, interpretative doubts arise due to the expression used by the legislator in Art. 196 CC, that is "religious feelings," which is a vague term not defined in the Criminal Code.

The use of the word "feeling" in the regulation in question seems to indicate what is subjective and intangible. Feelings by nature are a certain state of mind of a specific person who may assess them only on the basis of

\footnotetext{
${ }^{4}$ Statistical data from the website: https://statystyka.policja.pl/st/kodeks-karny/przes tepstwa-przeciwko-5/63492,Obraza-uczuc-religijnych-art-196.html [accessed: 21.05.2021].
} 
subjective criteria. One must also bear in mind that each person has the right to perceive religiousness differently and to experience and express their belief in their own individual way. There is no appropriate canon of behaviour covering persons who think themselves as religious which would constitute a certain basis for the assessment of whether a given person may be seen as religious or not.

Legal scholars and commentators understand offending religious feelings as such behaviour which, objectively or with reference to a specific person or group, is perceived as derogatory or degrading. Therefore, it is an emotional response of a given person, which directly relates to degrading behaviour towards an object, sign, symbol or person that is a medium of religious values. Questions about the assessment of objectivity of a given behaviour arise against such an understanding of the concept of "religious feelings." One cannot rule out a situation in which the behaviour of the perpetrator is perceived in a different way by individual persons despite the fact that all of them will declare affiliation with a particular faith. In his work Religion without God, R. Dworkin points out that a religious attitude does not require or assume the existence of God, but it has a deeper meaning which is expressed in the opinion that there are objective values in the world and that human life has a specific purpose. In R. Dworkin's opinion, a person who presents a religious attitude acknowledges the reality and independence of values, which is expressed in the fact that human life has objective worth, thereby each person bears an inherent and inalienable responsibility for their own life and the life of others, and, what is more, nature is a miracle, it is beautiful and sublime in itself. A human, in turn, accepts these assumptions "as gospel," which is why positions that reject the reality of values, expressed in e.g. naturalism, and other positions in which values exist but only in a certain dependence, e.g. if there is no God, values have no raison d'être [Dworkin 2014, 97-145], are the opposite to a religious attitude.

The Supreme Court also attempted to identify the term "religious feelings" and in its judgment of 6 April 2004 it pointed out that "they can be defined as a mental state whose essence involves taking an internal stance on past, present and future events, directly or indirectly related to religion as a form of social awareness that encompasses beliefs concerning 
the meaning and purpose of the existence of man, humanity and the world." 5

The lack of a legal definition of the term "religious feelings" leads to uncertainty, unacceptable in the legal system, which is manifested in the fact that one does not know what exactly may be classified as an object of insult. This, in turn, leads to a dangerous freedom in interpreting the provision in question thus providing a real possibility for abusing it. In consequence, everyone who subjectively feels that his religious feelings were insulted may report a suspected offence and involve judicial institutions in the protection of values that are not sufficiently specified, which directly affects a further course of court proceedings.

\section{SUBJECT OF OFFENCE}

The prohibited act under Art. $196 \mathrm{CC}$ falls under the group of common crimes. This means that it may be committed by any person capable of holding criminal liability, i.e. a person who while the prohibited act was being committed had attained the age of 17 and was sane. It must be reserved that Art. $169 \mathrm{CC}$ was not included in the catalogue of offences for which a minor before he attains the age of 15 years may be held criminally liable in exceptional cases. It is essential that it is irrelevant for criminal liability whether the offender himself is a follower of a given religion or if he does not adhere to any religious beliefs at all and considers himself an atheist [Kruczoń 2011, 54-55].

\section{MATERIAL SIDE OF THE CRIME OF OFFENDING RELIGIOUS FEELINGS}

Art. 169 CC penalises behaviours of persons which involve offending religious feelings of other people. Therefore, the misdemeanour stipulated in Art. $169 \mathrm{CC}$ has a causal nature and the action involves such behaviour on the side of the offender which is perceived by the members of a given religious community as degrading or insulting towards the object of these

${ }^{5}$ I CK 484/03, OSNC 2005, no. 4, item 69. 
feelings, and in particular the object of religious worship or places of celebration of religious acts [Warchałowski 2002, 70]. In the opinion of the Sejm, "Art. 196 CC does not refer directly to the worldview of the potential perpetrator, but only to certain behaviours that may be considered insulting. An insult involves demonstration of contempt, that is a lack of respect or disregard. Therefore, there is no relationship between expressing contempt and formulating statements that are a manifestation of a certain view. The essence of an insult does not consist in a substantive statement that judges properties and actions of a given person, based on existing or presumed facts, but it a statement that undermines personal dignity due to its form, not content." 6 M. Filar, in his commentary to Art. 169 CC writes that criticising the views expressed by representatives of a given faith or its doctrines is not an insult or contempt. Using symbols of this faith for artistic creation will not be an insult either if the artist's intention is not to express contempt for such symbols and the form and content of the creation do not contain degrading elements. The subjective feelings of persons are not enough in order to recognize that we are dealing with the offending of religious feelings of other people by publically insulting objects referred to in the provision analysed, because the perpetrator's actions must be objectively insulting and offensive [Filar 2016, 1203-204]. A similar stance on this subject is presented by W. Wróbel who believes that a statement or behaviour which expresses one's negative attitude towards an object of religious worship or which uses this object as an element of artistic creation is not insulting in nature as long as due to its form and content it does not include degrading or insulting elements. Moreover, the author points out that the principle of proportion of goods must be respected and that the subsidiarity requirement and also an individual artistic purpose of the perpetrator's actions must be met at that [Wróbel 2017, 641-43].

It needs to be highlighted that the condition of criminality in this case consists in the public manner of the perpetrator's actions, whereby such behaviour may take the form of a public insult of an object of religious worship or of a place dedicated to the celebration of religious rites [Zgoliński 2020, 976-77]. Legal scholars and commentators point out that this

\footnotetext{
${ }^{6}$ Judgment of the Constitutional Tribunal of 6 October 2015, SK 54/13, OTK-A 2015, no. 9, item 142 .
} 
offence may be committed as an action or omission. The perpetrator's actions may be carried out as a verbal statement, a gesture or a tangible expression of one's views, e.g. in the form of a painting or drawing. It may also take the form of omission, as pointed out by W. Wróbel, e.g. when an administrator of a website on which content that offends religious feelings of other people is posted fails to respond or when a person responsible for the content of specific press materials does not react [Wróbel 2017, 653$55]$. The public nature of the perpetrator's actions is essential in this case. The Supreme Court, in its decision of 5 March 2015 (II KK 274/14), pointed out that only such insult of an object of religious worship that is made publically meets the requirements of an offence stipulated in Art. 169 CC. The public nature of the offence under Art. $169 \mathrm{CC}$ boils down to the fact that insulting an object of religious worship may be noticed by a greater and undefined number of people [Petasz 2016, 56-61]. Legal scholars and commentators also signal that the activity will gain a public character also when the perpetrator uses appropriate tools in order to record it and then distributes the recorded material in other circles of people, e.g. on-line or in mass media [Grześkowiak and Wiak 2012, 882-84]. The above leads to a conclusion that a perpetrator's action that involves offending religious feelings of other people in the private sphere will not be penalized because the content of the utterance will not reach wider circles.

\section{OBJECT OF RELIGIOUS WORSHIP}

An object of religious worship must be understood as anything that a given religious community reveres as an object of such worship. These may be material things such as: a figure depicting personification of a god or a saint, a painting, vestments, a crucifix, sacramental bread, a rosary or a relic [Makarska 2005, 180-86]. M. Filar confirms the above pointing out that symbols of a given faith in the form of the crucifix or the Star of David and also liturgical objects (e.g. sacramental bread) or a material personification of gods or deities in the form of monuments or statues may be considered as objects of religious worship [Filar 2016, 1204]. In the opinion of J. Krukowski, "the object of religious worship" means God perceived as a person or in another way, and also an item, symbol, image specific words or names which according to a given religious community are 
regarded as holy and worthy of respect and reverence" [Krukowski 2007, 294]. ${ }^{7} \mathrm{~J}$. Wojciechowska additionally states that rituals and prayers identified by a given faith must also be placed in the catalogue of objects of religious worship [Wojciechowska 2001, 84-85].

There is no doubt that an object of religious worship in the form of a monument, figure, crucifix or paining may be insulted. A ritual may also be insulted by organizing it in a ridicule-like, degrading or vulgar manner. The elements enumerated above may also form insulting elements of a prayer. However, one cannot agree with the position presented by J. Krukowski in terms of opportunities of the possible insulting of the name of a holy person. It is because an insult is inseparably related to the material element that may be defined and identified. When a person named Anna is being insulted, the perpetrator does not insult the name of this person, but the specific woman. Given the above, in must be concluded that under the provision in question names of saints cannot be the subject of the acts investigated.

\section{PLACE DEDICATED TO THE CELEBRATION OF RELIGIOUS RITES}

Places dedicated to the celebration of religious rites are understood as places which are adjusted to practising religious celebrations, have a permanent or temporary nature in the form of churches or chapels and also adjacent space, e.g. a church yard or a chapel yard if it becomes a place where celebrations outside the building of the place of worship are held. These places are subject to protection under Art. $169 \mathrm{CC}$ only during the performance of religious rites. Legal scholars and commentators also assume that such places must also include streets and squares that are made available for the time of religious rites, e.g. to organise a procession on Corpus Christi [Piórkowska-Flieger 2008, 375-79]. However, protection does not extend to places in which people gather spontaneously and incidentally wanting to jointly celebrate the rites or to say prayers e.g.in one's garden [Filar and Berent 2016, 1205].

\footnotetext{
${ }^{7}$ The author lists: a cross, a painting, figures, names of Jesus and Mary, etc. as examples of objects of religious worship of Roman Catholics.
} 
The Code of Canon Law points out that holy places are those which have been consecrated or blessed and pursuant to provisions of liturgical books have been designated for worshipping God and for burying the believers. ${ }^{8}$ The above shows that a condition determining a given place as a sacred place, dedicated to the public celebration of rites, according to canon law consists in performing the act of consecration or blessing. The definition presented shows that sacred places should also include cemeteries since they are commonly believed as places of performing religious acts.

\section{PERSONAL SIDE OF THE CRIME OF OFFENDING RELIGIOUS FEELINGS}

An analysis of the personal side of offending religious feelings as a crime shows discrepancies in the views of legal scholars and commentators on this issue. Some criminal law scholars point out that the crime under Art. 169 CC may be committed only deliberately with direct intention. Such a position is presented by J. Wojciechowska, who state that in the personal aspect the act specified in Art. $169 \mathrm{CC}$ is deliberate in nature. The authors point out that the verb prerequisites included in this provision, i.a. "offends" and "insults" are deliberate prerequisites and consequently limit the personal side in terms of the form of intentionality to deliberate intention [Wojciechowska 2006, 781-83].

A different view is presented by M. Filar who states that the crime under Art. 169 CC has a deliberate nature but may be committed both in the form of direct intention and possible intention [Filar 2010, 933-34]. A similar position is presented by $€$. Pohl and S. Czepita who indicate that from the point of view rules of linguistic interpretation one must definitely assume that the prohibited act stipulated in Art. $169 \mathrm{CC}$ may be committed with indirect intention and possible intention alike [Pohl and Czepita 2012, 78]. This position is also confirmed by the Supreme Court, which in its resolution of 29 October 2012, points out that "an offence specified in

${ }^{8}$ Codex Iuris Canonici auctoritate Ioannis Pauli PP. II promulgatus (25.01.1983), AAS 75 (1983), pars II, p. 1-317. 
Art. $169 \mathrm{CC}$ is committed by anyone who by means of their direct or possible intention meet all premises of this misdemeanour."

Given the above, the view postulating that the prohibited act under Art. 169 CC may be committed in both forms of intentions deserves approval. This position is also confirmed by the Supreme Court in its explanatory memorandum to the resolution of 29 October 2012, that states that "the requirements of this crime will be met when the perpetrator's actions involving the public insulting of an object of religious worship (or a place designated for the public celebration of religious rites) are aimed directly at executing this act, and also when the perpetrator publically undertakes such offending actions which due to their form are commonly believed to have an insulting character. Thereby, he either wants to offend religious feelings of other people or by anticipating such consequences of his behaviour he agrees to them." 10

\section{CONCLUSION}

The legal analysis of Art. $169 \mathrm{CC}$ leads to the following conclusions:

1) The direct subject-matter of protection covers the freedom of individual persons from any behaviour that insults their religious feelings which in consequence makes them feel a mental discomfort associated with the sense of a lack of respect for their faith and values professed.

2) The expression "religious feelings" used by the legislator in the content of the article discussed trigger interpretative doubts. The lack of a legal definition which would specify a framework of this term may cause problems in establishing what is qualified as subject-matter of protection under Art. $169 \mathrm{CC}$ and what is not. A historical and linguistic definition of this regulation allows a conclusion that the legislator did not aim to cover with protection the religious feelings of citizens understood as a certain mental state, but religion as a community. Given the above, the postulate of the need to amend the content of Art. $169 \mathrm{CC}$ so as to eliminate the emerging interpretative doubts seems valid. In the author's opinion, an adequate solution would involve creating a legal definition of the term "re-

\footnotetext{
${ }^{9}$ I KZP 12/12, OSNKW 2012, no. 11, item 112.

${ }^{10}$ Ibid.
} 
ligious feelings" or specifying in Art. $169 \mathrm{CC}$ that protection covers religion (understood as a whole).

3) The crime involving offending religious feelings falls under the group of common offences. Therefore, any person may be a perpetrator if at the moment of commission of the act they have attained the age of 17 years and are sane.

4) The material side of the prohibited act specified in Art. 169 CC involves the public insulting of an object of religious worship or a place dedicated to the public celebration of religious rites. It is a causal (substantive) crime, thereby for it to exist there must be an effect in the form of offending religious feelings of other persons.

5) The personal side features intent. Legal scholars and commentators present different views when specifying the scope of the act stipulated in Art. 169 CC, recognizing that it may be carried out only with direct intention or by allowing the possibility of occurrence of both direct intention and possible intention. One must point to the correctness of the view that allows both the direct and possible intention, according to the position presented by M. Filar, Ł. Pohl, S. Czepita and the Supreme Court.

\section{REFERENCES}

Cebula, Sławomir. 2011. Prawa i wolności we wspótczesnej Polsce. Kraków: Nomos.

Dworkin, Ronald. 2014. Religia bez Boga. Translated by Bogdan Baran. Warszawa: Fundacja Aletheia.

Filar, Marian. 2010. "Przestępstwa przeciwko wolności sumienia i wyznania." In Kodeks karny. Komentarz, ed. Marian Filar, 933-34. Warszawa: LexisNexis.

Filar, Marian. 2016. “Obraza uczuć religijnych.” In Kodeks karny. Komentarz, ed. Marian Filar, 1203-207. Warszawa: Wolters Kluwer Polska.

Garlicki, Leszek. 2009. Polskie prawo konstytucyjne. Zarys wykładu. Warszawa: Wolters Kluwer Polska.

Grześkowiak, Alicja, and Krzysztof Wiak, ed. 2012. Kodeks karny. Komentarz. Warszawa: Wydawnictwo C.H. Beck.

Hypś, Sławomir. 2015. "Przestępstwa przeciwko wolności sumienia i wyznania." In Kodeks karny. Komentarz, ed. Alicja Grześkowiak, and Krzysztof Wiak, 975-76. Warszawa: Wydawnictwo C.H. Beck.

Kruczoń, Erwin. 2011. "Przestępstwo obrazy uczuć religijnych.” Prokuratura i Prawo 2:54-55.

Krukowski, Józef. 2007. Polskie prawo wyznaniowe. Warszawa: Wolters Kluwer Polska. 
Makarska, Małgorzata. 2005. Przestępstwa przeciwko wolności sumienia i wyznania $w$ Kodeksie karnym z 1997 r. Lublin: Towarzystwo Naukowe KUL.

Petasz, Paweł. 2016. "Zagadnienie wymogu publicznego charakteru zachowania się sprawcy przestępstwa z art. 196 k.k. oraz możliwości wyłączenia odpowiedzialności karnej przez uznanie jego działania za twórczość artystyczną. Glosa do postanowienia SN z dnia 5 marca 2015 r., II KK 274/14." Gdańskie Studia Prawnicze Przeglad Orzecznictwa 2:56-61.

Piórkowska-Flieger, Joanna. 2008. "Przestępstwa przeciwko wolności sumienia i wyznania.” In Kodeks karny. Komentarz, ed. Tadeusz Bojarski, 375-79. Warszawa: LexisNexis.

Pohl, Łukasz, and Stanisław Czepita. 2012. "Obraza uczuć religijnych, kiedy mówimy o przestępstwie." Prokuratura i Prawo 12:75-78.

Pyclik, Krzysztof. 2002. "Wolność sumienia i wyznania w Rzeczypospolitej Polskiej (założenia filozoficzno-prawne).” In Prawa i wolności obywatelskie w Konstytucji RP, ed. Bogusław Banaszak, and Artur Preisner, 437-38. Warszawa: Wydawnictwo C.H. Beck.

Warchałowski, Krzysztof. 2002. "Prawnokarna ochrona wolności religijnej w Polsce w latach 1932-1997." Studia z Prawa Wyznaniowego vol. 4, 59-72.

Wojciechowska, Janina. 2001. "Przestępstwa przeciwko wolności sumienia i wyznania." In Barbara Kunicka-Michalska, and Janina Wojciechowska, Przestępstwa przeciwko wolności, wolności sumienia i wyznania, wolności seksualnej i obyczajności oraz czci i nietykalności cielesnej. Rozdziały XXIII, XXIV, XXV i XXVII Kodeksu karnego. Komentarz, 84-86. Warszawa: Wydawnictwo C.H. Beck.

Wojciechowska, Janina. 2006. "Rozdział XXIV Przestępstwa przeciwko wolności sumienia i wyznania." In Kodeks karny. Część szczególna. Vol. 1: Komentarz do artykułów 117-221, ed. Andrzej Wąsek, 781-83. Warszawa: Wydawnictwo C.H. Beck.

Wróbel, Włodzimierz. 2017. "Rozdział XXIV Przestępstwa przeciwko wolności sumienia i wyznania." In Kodeks karny. Część szczególna. Vol. 2. Part 1: Komentarz do art. 117-211a, ed. Andrzej Zoll, 641-49. Warszawa: Wolters Kluwer Polska.

Zgoliński, Igor. 2020. "Przestępstwa przeciwko wolności sumienia i wyznania." In Kodeks karny. Komentarz, ed. Violetta Konarska-Wrzosek, ed. 3, 976-79. Warszawa: Wolters Kluwer Polska.

\section{The Crime of Offending Religious Feelings - Legal Analysis}

\section{Summary}

This paper presents a legal analysis of the crime stipulated in Art. 196 of the Criminal Code. Due to the limited framework of this study, the author confines her reflections to the analysis of the views of legal scholars and commentators on the subject matter and subject of protection and the material and personal side of the crime of offending religious feelings. Moreover, the author points to the lack of a statutory definition of the term "religious feelings," demonstrating at the same time the legal consequences of such a state of affairs. 
The author postulates that Art. 196 of the Criminal Code be amended in terms of the concept analysed, pointing to the need to establish a legal definition of the term "religious feelings" or to exchange it with a concept defined so as to rule out freedom in interpretation of the scope of subject matter of protection under Art. 196 of the Criminal Code.

Keywords: religious rights and freedoms; subject matter of protection; religious feelings; insult

\section{Przestępstwo obrazy uczuć religijnych - analiza prawna}

\section{Streszczenie}

W artykule przedstawiono analizę prawną przestępstwa, o którym w art. 196 Kodeksu karnego. Ze względu na ograniczone ramy niniejszego opracowania Autor ogranicza swoje rozważania do analizy poglądów prawników i komentatorów dotyczących przedmiotu ochrony oraz materialnej i osobowej strony przestępstwa obrazy uczuć religijnych. Ponadto Autor wskazuje na brak ustawowej definicji pojęcia „uczucia religijne”, wykazując jednocześnie konsekwencje prawne takiego stanu rzeczy.

Autor postuluje, aby art. 196 Kodeksu karnego został zmieniony pod kątem analizowanego pojęcia, wskazując na potrzebę ustalenia prawnej definicji pojęcia „uczucia religijne” lub zastąpienia go pojęciem tak zdefiniowanym, aby wykluczyć swobodę interpretacji zakresu przedmiotu ochrony na podstawie art. 196 Kodeksu karnego.

Słowa kluczowe: prawa i wolności religijne; przedmiot ochrony; uczucia religijne; zniewaga

Informacje o Autorze: Mgr MONIKA NIEDŹwIECKA - doktorant, Wydział Prawa i Administracji, Uniwersytet Szczeciński; adres do korespondencji: ul. Narutowicza 17A, 70-240 Szczecin, Polska; e-mail: monika.niedzwiecka@usz.edu.pl; https:// orcid.org/0000-0002-4341-5324 